\title{
Reviews and Practice of College Students Regarding Access to Scientific Knowledge: A Case Study in Two Spanish Universities
}

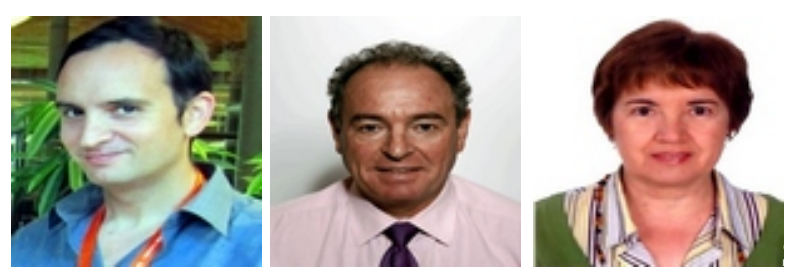

José Manuel Sáez López¹, Jose María Ruiz Ruiz², and Maria-Luz Cacheiro González ${ }^{1}$ ${ }^{1}$ Spanish National University of Distance Education (UNED), Spain, ${ }^{2}$ Complutense University of Madrid, Spain

\section{Abstract}

This study analyzes the concepts, attitudes, and practices of 327 pedagogy students from two major Spanish universities related to the process of finding academic information utilizing open access. A training program has been developed through an innovation project (PIMCD) to address the problem of the lack of university training designed to enable students to access reliable sources of scientific knowledge. A mixed questionnaire with a pretest-posttest design, applying a descriptive analysis, a factor analysis, and a Wilcoxon test was administered to students. The results show that it is essential to provide information and training to encourage university students to learn how to find and manage rigorous and reliable sources of information. While searching for academic information, Spanish students tend to focus on the use of Google and, to a lesser extent, Google Scholar. Although there are no significant limitations of access to Spanish language articles, students' attitudes remain very positive towards the concept of open access. In short, in accordance with the study results, the promotion of educational activities relating to the search for and selection of information and the use of reliable and rigorous academic content is highly recommended in the university context.

Keywords: ICT; open access; educational innovation; training 


\section{Introduction}

Currently, obtaining access to knowledge is relatively easy due to the large number and variety of studies available on the Internet. "Today the average researcher at a university has instant access to a much broader range of journal articles than ever before during the print era" (Björk et al., 2010).

It should be noted that studies published in various scientific journals are funded with public money. Therefore, from an ethical perspective, content should be available to any reader. However, this does not occur as a result of several factors.

Currently, a considerable number of scientific journals demand subscriptions and fees for access to their articles. This situation has caused concern when publishing due to the fact that the majority of the work (i.e., creation and revision) is done freely by the community. Editors take advantage of this situation by charging fees to access articles and journals, thereby profiting from the editing process.

One possible solution is found in open access, which is the practice of providing free and unrestricted access to peer-reviewed articles in scientific journals over the Internet. Open access arose in the 1990s as a reaction to the increase of subscription prices at a rate considerably higher than inflation. In recent years, there have been open access publishers who simply act as suppliers. Through the Directory of Open Access J ournals (DOAJ ), it is possible to access over 5,000 peer reviewed journals.

\section{Theoretical Framework}

The Budapest Open Access Initiative details the importance of this approach and defines open access:

By "open access" to this literature, we mean its free availability on the public internet, permitting any users to read, download, copy, distribute, print, search, or link to the full texts of these articles, crawl them for indexing, pass them as data to software, or use them for any other lawful purpose, without financial, legal, or technical barriers other than those inseparable from gaining access to the internet itself. The only constraint on reproduction and distribution, and the only role for copyright in this domain, should be to give authors control over the integrity of their work and the right to be properly acknowledged and cited. (Open Society Institute, 2002, p. 1) 
The Bethesda Statement on Open Access Publishing (2003) details the conditions that open access must have. The Berlin Declaration on Open Access to Knowledge in the Sciences and Humanities (2003) establishes open access as a worthwhile practice, ideally requiring the active commitment of all individual producers of scientific knowledge and holders of cultural heritage.

Furthermore, although most studies conclude that open access improves the diffusion of research (Swan, 2010), others argue that open access, that is, free dissemination, undermines copyright law. In addition, problems may arise in the process of peer review. Some organizations, such as the International Publishers Association and the Association of American Publishers, are not in favor of open access.

\section{Open Access Advantages}

Open access facilitates the availability of research results and encourages an increase in research productivity. Internet search engines and the posting of articles in open access repositories greatly increase the accessibility of publications. Several studies (Antelman, 2004; Craig, Plume, McVeigh, Pringle, \& Amin, 2007; Harnad \& Brody, 2004; Lawrence, 2001; Norris, Oppenheim, \& Rowland, 2008; Wagner, 2010; Zhang, 2006) have highlighted a significant increase in citations of articles under this policy.

The main advantage of open access is that it facilitates the availability of articles over the Internet, thereby increasing the likelihood that the study will be viewed and cited. Accordingly, open access promotes the possibility of reaching a wider audience (Shields, Rangarajan, \& Stewart, 2012).

Other studies highlight the benefits of open access related to the acceleration of the citation of research (Eysenbach, 2006; Institute for Scientific Information, 2004), even in low-income countries (Evans \& Reimer, 2009; Norris, Oppenheim, \& Rowland, 2008; Zhang, 2006). "As we see OA articles are distributed much more widely and have equal or better likelihood of being cited by other scholars" (Anderson, 2013, p. 90).

The research goal of Swan (2010) was to determine whether there was an overall increase in citations for an open access body of literature. Swan's research reveals 27 studies concluding that open access increases the rate of citation considerably. However, four studies conclude that open access does not result in an increase in citation rates. Therefore, the data clearly support the use of open access. Open access articles have a greater research impact than articles that are not freely available (Antelman, 2004).

Journals have an essential function in the diffusion of knowledge through research. "Article downloads and citations measure two different dimensions of scientific knowledge transfer. The first measures general interest in a particular new piece of knowledge; the second measures the incorporation of that knowledge into a new document" (Davis, 2011, p. 2132). 
Despite the scientific evidence suggesting that open access increases the citation of articles, some authors argue that it is difficult to determine whether the relationship between open access and citations is causal, or whether the relationship is merely spurious (McCabe \& Snyder, 2011). "It is not surprising that providing free access has little (if any) effect on article citations" (Davis, 2011, p. 2133).

The essential factors influencing the rate of citation are the quality, relevance, originality, and influence of the study (Swan, 2010), although it is evident that there are a variety of factors affecting citation and readership. "Free access to scientific articles increases readership (as measured by article downloads) and reaches a broader audience (as measured by unique IP addresses) but has no effect on article citations within the first 3 years after publication" (Davis, 2011, p. 2132).

\section{Open Access in the University Setting}

There is evidence regarding the benefits to practice and research resulting from the accessibility of good quality student research utilizing institutional digital repositories. Seventy percent of researchers use Google or Google Scholar as a primary tool for finding information. Norris, Oppenheim, and Rowland (2008) used a combination of different search engines and reported that $86 \%$ of articles could be found using either Google or Google Scholar. For reasons of economy, Google is a good option.

With the improved availability of research, there are a number of groups, such as college students, who benefit from this approach. Considering the advantages and simplicity of Google searches, access to scientific knowledge is relatively effortless. "The real beneficiaries of open access may not be the research community, which traditionally has excellent access to the scientific literature, but communities of practice that consume, but rarely contribute to, the corpus of literature" (Davis, 2011, p. 2133).

Open access provides advantages to teaching and learning processes in the university context, as it encourages the use of the scientific knowledge available in all subject areas. "We are in the midst of a rapid transition from closed to open access publishing. This disruptive transition benefits ordinary citizens and scholars" (Anderson, 2013, p. 93).

Students can access research to support or supplement the knowledge they are acquiring in their disciplines. New technologies and communication mechanisms have led to an increase in the significance of student work. Student papers may contain knowledge and information that, given the right circumstances, should be shared with the world (Levin, Burbules, \& Bruce, 2005).

It is noteworthy that students need information and access to knowledge in their fields. Students need access to the latest research in their disciplines to have a complete education in their fields of study. Limited access is a serious problem for students, because under these circumstances, they only have the option of working with the information available, and may not have access to the most relevant knowledge. 
Open access is important to ensure that students develop quality research and are not artificially limited. "Quality student research is an underused resource that needs to find its rightful place in the knowledge realm" (Shields, Rangarajan, \& Stewart, 2012, p. 20). Student work, aided by open access, can enhance the reputation of an institution and contribute useful knowledge (Lynch \& Lippincott, 2005).

Only the largest, most well-funded institutions have the opportunity to provide their students with the information and knowledge they need and the latest research in their fields of study. As a result, there is inequality of access. "I would only add that the importance of creating open access to these different landscapes and links will certainly be a boon for those faculty and students who do not otherwise have access to journals or indexes" (Willinsky, 2006, p. 170).

\section{Aims}

The main objective is to analyze the knowledge, attitudes, and practices utilized by college students to find academic information in journal articles and to assess the possible benefits of open access.

The specific objectives are:

- Check the functionality of free information access in the university.

- Assess the attitudes of college students who attended the open access training program included in the applied innovation project (PIMCD).

- Detect the open access training needs of students in the university.

- Analyze the practices of university students as they develop information seeking methods.

\section{Method}

\section{Participants}

The study sample consists of 327 university students belonging to eight different groups of first and second degree courses in pedagogy. Two hundred twenty-one students attend Complutense University in Madrid and 106 students attend Murcia University, two major universities in Spain. In the sample, 76.5\% are female students and 23.5\% are male students. The contingency analysis is not detailed because there are no significant differences regarding gender, group, or college. 


\section{Procedure and Instruments}

The present study proposes two dimensions which address the research objectives through a quasi-experimental method. Perceptions and practices reported by students are analyzed utilizing this process. This kind of research is intended to describe the individual experience in particular environments (Creswell, 2003).

The study is part of the innovation project (PIMCD) approved in the academic year 2012-2013 at Complutense University in Madrid, entitled Uso de las redes sociales, las herramientas de Acceso Libre, el "ABP", las tutorías y el autoaprendizaje para evaluar las competencias en el grado. ${ }^{1}$

The project includes a four month training process during which students engage in activities and case studies and attend sessions and presentations related to the concept of open access. Also, students search for scholarly information using different methodological strategies.

A mixed questionnaire is given before (pretest) and after (posttest) the implementation of the project. Once the information is gathered, we apply a descriptive analysis, a factor analysis, and a Wilcoxon test to measure significant differences before and after the training program.

Data triangulation can ensure that there is sufficient evidence to support the validity of the results and minimize error variance (Goetz \& LeCompte, 1988). The data triangulation (Cohen, Manion, \& Morrison, 2000) was implemented using quantitative information collected in the different tests as well as the analysis of the open questions.

${ }^{1}$ (Universidad Complutense. Vicerrectorado de Evaluación de la Calidad, referencia 90. Resolución 7-02-2013 http://www.ucm.es/data/cont/docs/3-2013-02-20- 
Table 1

Research Dimensions, Indicators, and Instruments

\begin{tabular}{|c|c|c|}
\hline Dimensions & Indicators & Instruments \\
\hline \multirow{5}{*}{$\begin{array}{l}\text { Dimension 1: } \\
\text { Concepts and } \\
\text { opinions regarding } \\
\text { open access }\end{array}$} & Knowledge of the concept of open access & \multirow{6}{*}{$\begin{array}{l}\text { Questionnaire } \\
\text { Wilcoxon test } \\
\text { Pretest- posttest }\end{array}$} \\
\hline & Attitudes towards open access & \\
\hline & Training needs related to open access & \\
\hline & Reviews about journals policy & \\
\hline & Knowledge regarding tools for finding information & \\
\hline \multirow{5}{*}{$\begin{array}{l}\text { Dimension 2: } \\
\text { Using open access } \\
\text { to access to } \\
\text { knowledge }\end{array}$} & Theoretical foundation of work & \\
\hline & Management of search engines & \multirow{4}{*}{$\begin{array}{l}\text { Factor analysis } \\
\text { Open questions }\end{array}$} \\
\hline & Use of open access databases & \\
\hline & Management of reliable information & \\
\hline & Use of open access repositories & \\
\hline
\end{tabular}

\section{Results}

\section{Descriptive Analysis and Wilcoxon Test}

The results of the study show a descriptive analysis in which the percentages are measured in two dimensions. The findings provide valuable information to consider. Moreover, it is important to analyze the value of the Wilcoxon test, which is based on the data provided by the pretest-posttest questionnaire. It allows us to ascertain whether there are significant differences before and after the implementation of the innovation project (PIMCD). The significance level is $0.01(\alpha=0.01)$. 
Table 2

Dimension 1: Concepts and Opinions Regarding Open Access. Post-Test Frequencies and Wilcoxon Test

\begin{tabular}{|c|c|c|c|c|c|}
\hline \multirow{2}{*}{$\begin{array}{l}\text { Dimension 1: Concepts and opinions regarding } \\
\text { open access }\end{array}$} & \multicolumn{4}{|c|}{$\begin{array}{c}\% \\
\text { Post test }\end{array}$} & \multirow{2}{*}{$\begin{array}{c}\text { Wilc. } \\
\text { test. } \\
0.01\end{array}$} \\
\hline & $\mathbf{1}$ & 2 & 3 & 4 & \\
\hline $\begin{array}{l}\text { 1.1. - I know the existence of open access journals to } \\
\text { support my work }\end{array}$ & 0.9 & 2.4 & 58.7 & 37.9 & $\mathbf{0 . 0 0}$ \\
\hline 1.2. - I believe that access to articles must be free & 0 & 0.6 & 19 & 80.4 & 0.02 \\
\hline $\begin{array}{l}\text { 1.3. - I know the Directory of open access J ournals } \\
\text { (DOAJ ) }\end{array}$ & 0.9 & 6.4 & 57.5 & 35.2 & $\mathbf{0 . 0 0}$ \\
\hline $\begin{array}{l}\text { 1.4. - I know what academic Google is (Google } \\
\text { Scholar) }\end{array}$ & 0 & 2.4 & 55.7 & 41.9 & $\mathbf{0 . 0 0}$ \\
\hline $\begin{array}{l}\text { 1.5. - I believe that subscriptions to journals are } \\
\text { unfair }\end{array}$ & 0.3 & 10.7 & 58.4 & 30.6 & $\mathbf{0 . 0 0}$ \\
\hline $\begin{array}{l}\text { 1.6. - Knowledge should be free and accessible } \\
\text { online }\end{array}$ & 0 & 0 & 23.5 & 76.5 & 0.35 \\
\hline 1.7. - Open access helps to develop society & 0 & 2.1 & 33 & 64.8 & $\mathbf{0 . 0 0}$ \\
\hline 1.8. - I know the ranking of journals in SCOPUS & 0.6 & 6.4 & 59.6 & 33.3 & $\mathbf{0 . 0 0}$ \\
\hline
\end{tabular}

Dimension one, which refers to the concepts and opinions about open access, highlights that $100 \%$ of students have a clear and positive attitude toward the free access to knowledge (Item 1.6). In addition, $99.4 \%$ of students in the sample consider that journal articles should be free (Item 1.2), and 97.9\% believe that open access helps to develop society (Item 1.7). In these items, there is no significant increase as shown in the Wilcoxon test data, revealing that students had prior positive attitudes regarding these issues.

However, we can see that subsequent to the applied training program, students indicate they have knowledge of various tools (Items 1.1, 1.3, 1.4, and 1.8) and the ability to find journal articles using open access. Students also indicate their belief that the current situation related to the publication of journal articles is unfair (Item 1.5).

The analysis of the values in the Wilcoxon test shows that the training program has led to a significant increase in students' awareness of the existence of open access journals to support their work (Item 1.1) and their knowledge regarding DOAJ , Google Scholar, and Scopus rankings (Items 1.3, 1.4, and 1.8). In addition, it reveals their critique of the 
current situation (Item 1.5) and positive attitudes toward the potential of open access to help develop society (Item 1.7).

Moreover, prior to the training program, very few subjects knew about the DOAJ (6.4\%) and Scopus rankings (6.1\%). Therefore, it has been effective and instrumental in providing this information (Figure 1, Items 1.3 and 1.8).

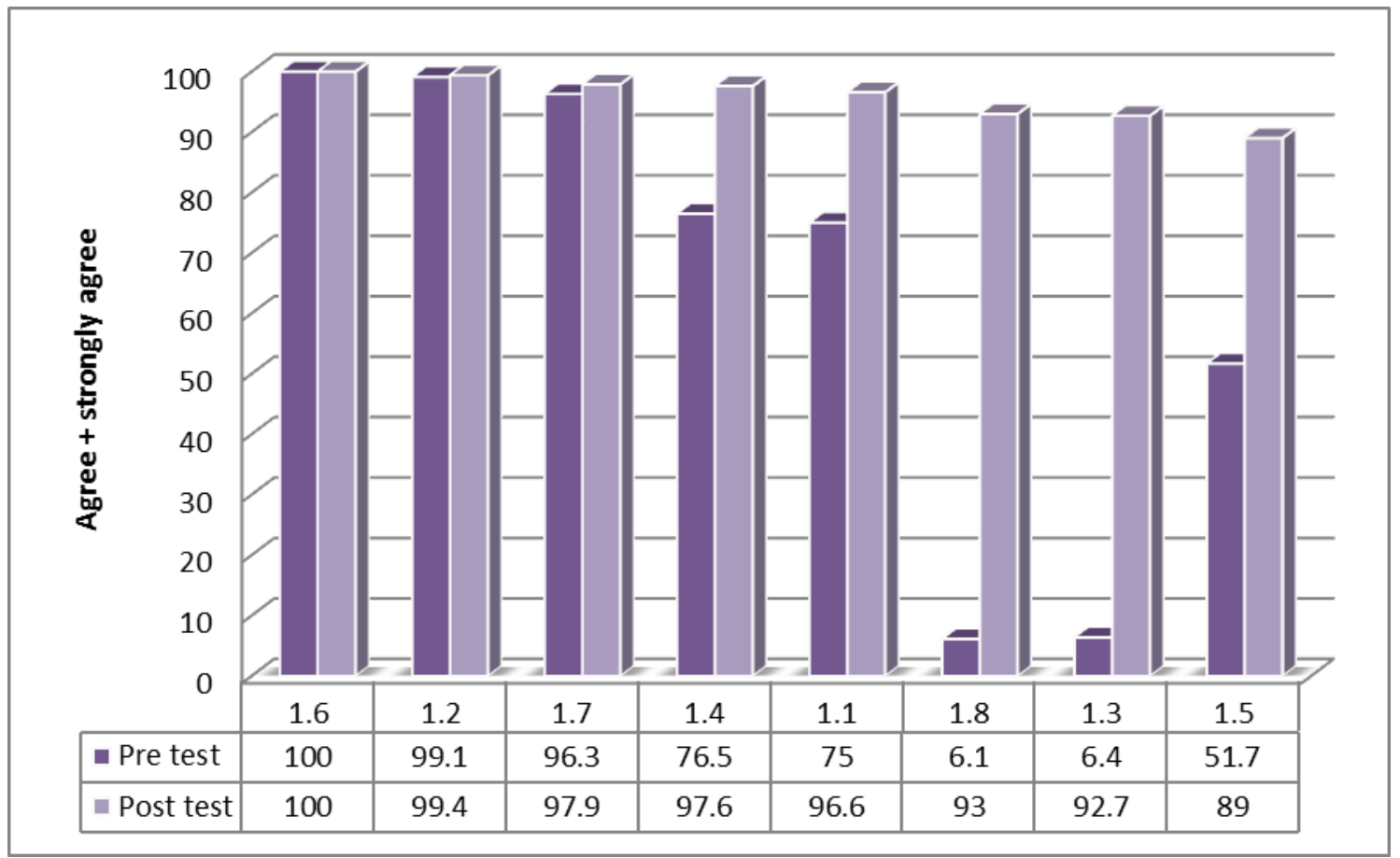

Figure 1. Dimension 1. Concepts and opinions regarding open access.

The data analyzed in Table 3 shows that $98.2 \%$ of students usually find free and available journal articles (Item 2.8), 97.9\% use Google to find theoretical information (Item 2.2), and 55.4\% use Google Scholar (Item 2.4). However, they engaged in these practices prior to the training program, so there is no significant improvement in these items.

The data shows that $85.4 \%$ of students have based their work on journal articles on some occasions (Item 2.6) and $80.4 \%$ of students often use journal articles to support their work (Item 2.1). In these cases, the training program has contributed to a significant improvement. 
Table 3

Dimension 2. Using OA to Access Knowledge. Frequencies in Post-Test and Wilcoxon Test

\begin{tabular}{|c|c|c|c|c|c|}
\hline \multirow{2}{*}{$\begin{array}{l}\text { Dimension 2: Using open access to obtain } \\
\text { knowledge }\end{array}$} & \multicolumn{4}{|c|}{$\begin{array}{c}\% \\
\text { Post test }\end{array}$} & \multirow{2}{*}{$\begin{array}{c}\text { Wilc. } \\
\text { test. } \\
0.01\end{array}$} \\
\hline & 1 & 2 & 3 & 4 & \\
\hline $\begin{array}{l}\text { 2.1. - I use open access scientific journals to } \\
\text { support my work }\end{array}$ & 2.4 & 17.1 & 48.6 & 31.8 & $\mathbf{0 . 0 0}$ \\
\hline $\begin{array}{l}\text { 2.2. - I use Google to find theoretical information } \\
\text { for my work }\end{array}$ & 0 & 2.1 & 23.5 & 74.3 & 0.18 \\
\hline $\begin{array}{l}\text { 2.3. - I use the Directory of Open Access J ournals } \\
\text { (DOAJ) }\end{array}$ & 47.7 & 46.2 & 4.6 & 1.5 & 0.107 \\
\hline 2.4. - I use Google Scholar & 13.1 & 31.5 & 35.5 & 19.9 & 0.54 \\
\hline 2.5. - I tend to use Wikipedia to support work & 39.4 & 35.5 & 22.6 & 2.4 & $\mathbf{0 . 0 0}$ \\
\hline $\begin{array}{l}\text { 2.6. - On occasion, I based my work on journal } \\
\text { articles }\end{array}$ & 0.6 & 14.1 & 55.4 & 30 & $\mathbf{0 . 0 0}$ \\
\hline $\begin{array}{l}\text { 2.7. - I use open access repositories (epubs, } \\
\text { eprints, DSpace, Fedora, Citebase ...) }\end{array}$ & 44.3 & 48.3 & 6.7 & 0.6 & $\mathbf{0 . 0 0}$ \\
\hline $\begin{array}{l}\text { 2.8. - When I find an article it is usually accessible } \\
\text { and available. }\end{array}$ & 0 & 1.8 & 23.2 & 74.9 & 0.46 \\
\hline
\end{tabular}

Only $6.1 \%$ of the students in the sample use the database Directory of Open Access J ournals (Item 2.3) and $12.7 \%$ of students use open access repositories (Item 2.7). Despite the low percentage, the training program has significantly improved the use of open access repositories (Item 2.7).

The analysis shows that $50.2 \%$ of students used Wikipedia to support their work in college (Item 2.5) prior to the training program. After the training program, the detailed posttest shows that only $25 \%$ of students continue to use Wikipedia to support their work, a significant reduction of this inadequate practice as detailed by the values of the Wilcoxon test. 


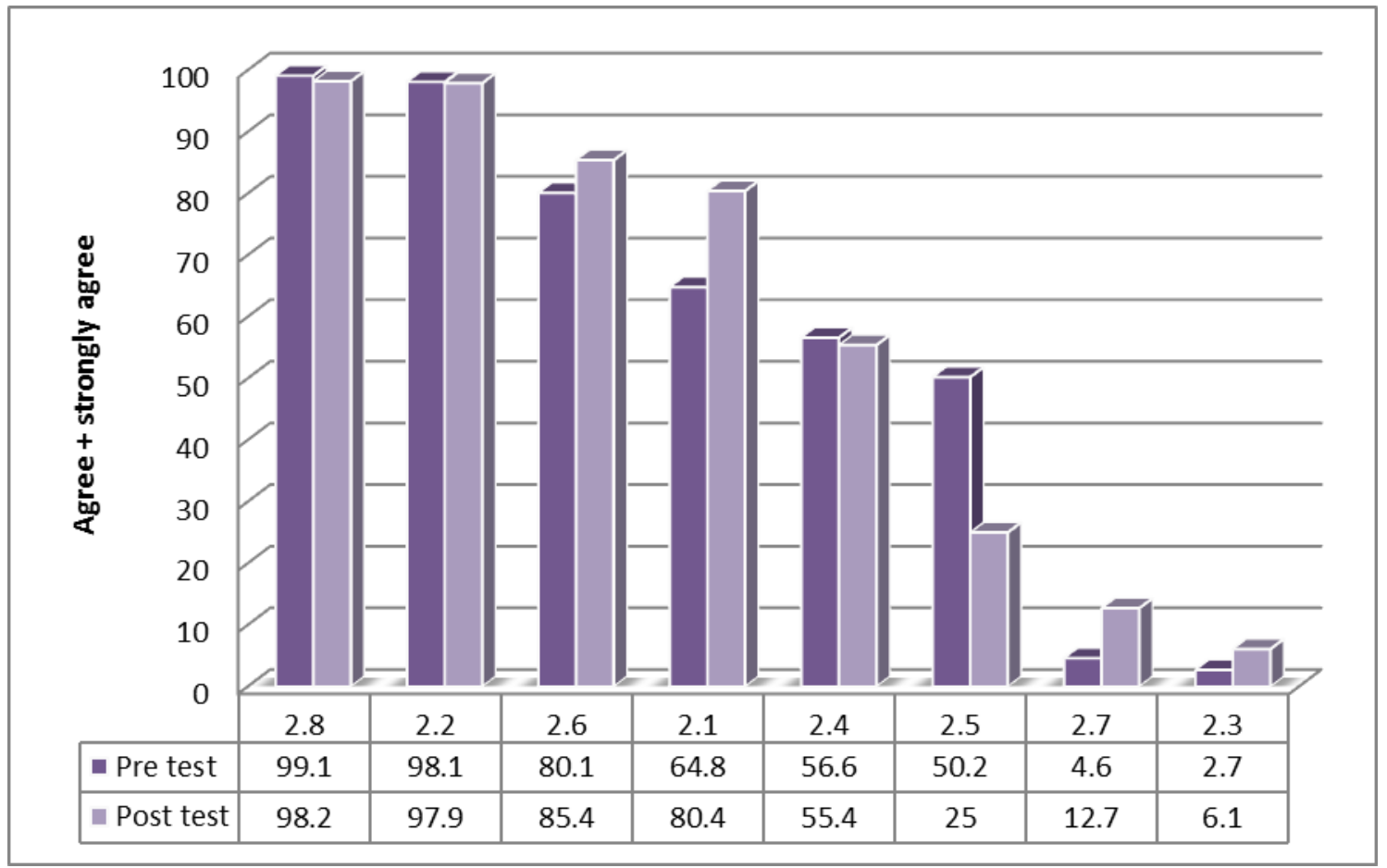

Figure 2. Dimension 2. Using open access to access knowledge.

\section{Open Questions}

The open questions are formulated to allow students to answer freely giving details and their particular perspective. This resulted in a number of responses of interest, which are analyzed by the program HyperResearch V 1.25. The students in the sample responded by providing diverse opinions openly as a result of the nature of the following open question: 2.9AB.-What tools do you use when you try to read an article and it is not freely available? 


\subsection{AB.-What tools do you use when you try to read an article and it is not freely} available?

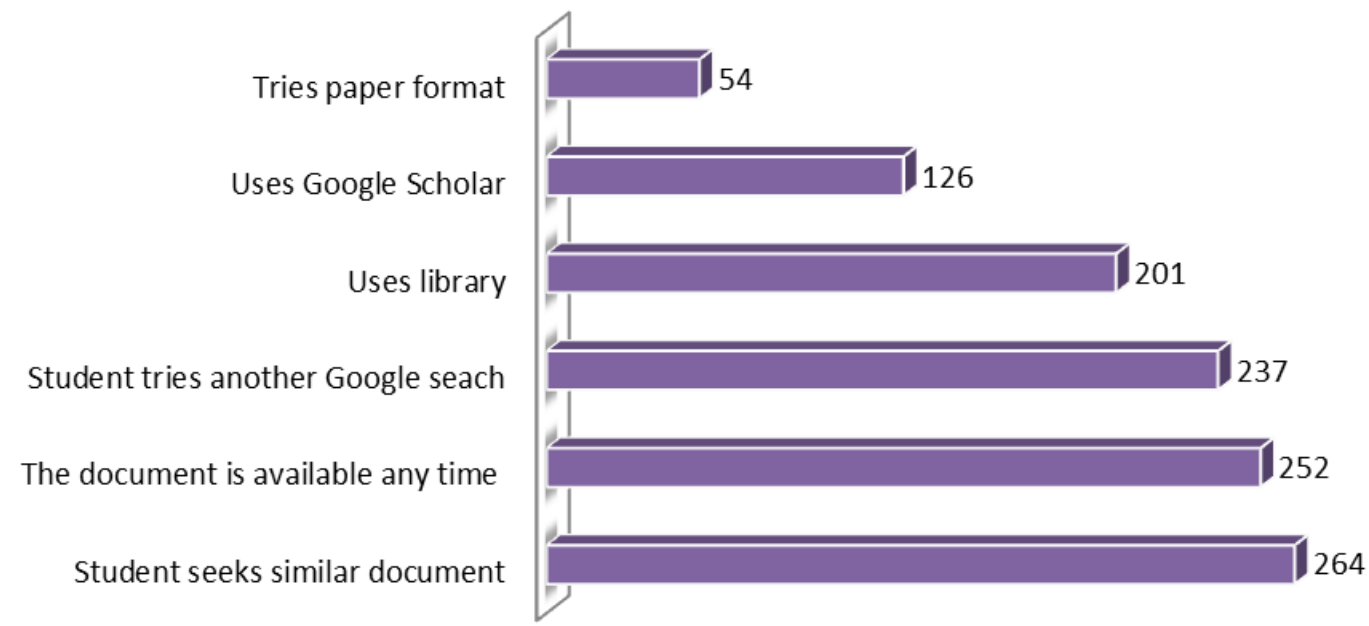

Figure 3. Open Question 2.9AB. Frequencies.

The most frequent responses suggest that students tend to find an available document. When they have access problems, they perform a new search using Google. To a lesser extent, they search in libraries, use Google Scholar, or opt for a paper format.

\section{Factor Analysis}

An exploratory factor analysis is proceeding in both of the dimensions studies in order to examine the underlying relationships between the variables. Data in Table 1 verify that it is constructive to proceed with a factorial analysis. The Kaiser-Meyer-Olkin test value is 0.825 and the Bartlett sphericity test shows a correlation that is significant (0001). The extraction method is principal components and the rotation method is Varimax with Kaiser (Table 4). Three factors are nominated:

1. tools to access knowledge,

2. importance of free access to social development,

3. knowledge of the availability of open access. 
Table 4

Dimension 1. Rotated Component Matrix. Extraction Method: Principal Components Analysis. Rotation Method: Varimax with Kaiser

\begin{tabular}{|l|c|c|c|}
\hline & \multicolumn{3}{|c|}{ Component } \\
\hline & 1 & 2 & 3 \\
\hline 1.1. - I know the existence of open access journals to support my work & & & .732 \\
\hline 1.2. - I believe that access to articles must be free & & .421 & .698 \\
\hline 1.3. - I know the Directory of open access J ournals (DOAJ) & -.428 & & \\
\hline 1.4. - I know what academic Google is (Google Scholar) & .690 & & \\
\hline 1.5. - I believe that subscriptions to journals are unfair & .613 & & \\
\hline 1.6. - Knowledge should be free and accessible online & & .678 & \\
\hline 1.7. - Open access helps to develop society & & -.648 & \\
\hline 1.8. - I know the ranking of journals in SCOPUS & .542 & & \\
\hline
\end{tabular}

In Table 3, the data provided by the analysis of Kaiser-Meyer-Olkin have a value of 0.782 and Bartlett's sphericity test is significant $(0.000)$. This information verifies that it is constructive to proceed with a factorial analysis. The extraction method is principal components analysis and rotation method is Varimax with Kaiser (see Table 5). Four factors are nominated:

1. theoretical foundations,

2. tools to access information,

3. ease of finding free content,

4. use of repositories. 
Table 5

Dimension 2. Rotated Component Matrix. Extraction Method: Principal Components Analysis. Rotation Method: Varimax with Kaiser.

\begin{tabular}{|l|c|c|c|c|}
\hline & \multicolumn{3}{|c|}{ Component } \\
\hline & 1 & 2 & 3 & 4 \\
\hline $\begin{array}{l}\text { 2.1. - I use open access scientific journals to support my } \\
\text { work }\end{array}$ & .662 & & & \\
\hline $\begin{array}{l}\text { 2.2. - I use Google to find theoretical information for my } \\
\text { work }\end{array}$ & & & - & .689 \\
\hline 2.3. - I use the Directory of Open Access J ournals (DOAJ) & & - & & \\
\hline 2.4. - I use Google Scholar & .491 & .401 & & \\
\hline 2.5. - I tend to use Wikipedia to support work & .414 & - & & \\
\hline 2.6. - On occasion, I based my work with journal articles & .687 & & & \\
\hline $\begin{array}{l}\text { 2.7. - I use open access repositories (epubs, eprints, DSpace, } \\
\text { Fedora, Citebase ...) }\end{array}$ & & & & .877 \\
\hline $\begin{array}{l}\text { 2.8. - When I find an article, it is usually accessible and } \\
\text { available }\end{array}$ & & & .568 & \\
\hline
\end{tabular}

\section{Conclusions}

Consistent with the objectives of the study, utilizing the information obtained in the various tests and with data triangulation, it can be concluded:

1. College students (100\%) have very positive attitudes and opinions regarding the free access to knowledge and they consider (97.9\%) that this approach contributes to the improvement of society (Table 2, Items 1.2, 1.5, 1.6, 1.7, and Table 4).

2. The training program implemented (PICMD) has statistically significant efficacy regarding students' knowledge of scientific journals and tools, that is DOAJ, Google Scholar, SCOPUS rankings, and repositories. The aforementioned program reduces the use of Wikipedia from $50.2 \%$ to $25 \%$. (Table 2, Table 3, Items 1.1, 1.3, 1.4, 1.8, and 2.5, 2.7, 2.9AB, Table 4, and Table 5). Therefore, it is necessary and advisable to implement training related to this information as part of university instruction.

3. The study shows that $97.9 \%$ of Spanish university students use Google to search academic content and 55.4\% use Google Scholar. Also, 98.2\% of the students in the sample find available and accessible articles every time they perform a search (Table 3, Items 2.2, 2.4, 2.8, and 2.9AB). 
4. Although $85.4 \%$ of students base their work on scientific journals, only $6.1 \%$ of students use the DOAJ and $12.7 \%$ use repositories (Table 3, Items 2.3, 2.6, and 2.7).

The attitudes of students towards open access are very favorable. Students use Google to find articles. Most consider Google an efficient option as indicated by Norris, Oppenheim, and Rowland (2008), who reported in their research that $86 \%$ of articles could be found using either Google or Google Scholar. Approximately half of the students use Google Scholar. However, databases and repositories are very rarely used by students.

The training activity (PICMD) has introduced students to open access and it has reduced the use of unreliable sources. The students have learned about databases, repositories, rankings, and other tools that provide access to reliable sources.

Spanish language journals are accessible and freely available. Accordingly, $98.2 \%$ of the students found academic content without problems (Item 2.8). Although limited access is a real problem for many students (Shields, Rangarajan, \& Stewart, 2012), the need for open access is not as urgent in the Spanish context.

In short, fostering university training aimed at helping students to find and manage rigorous and reliable sources of information is essential. Although students do not experience limited access to Spanish language articles, it is very important to provide them with the necessary training so they are able to perform a critical analysis when they manage information. It is important for students to utilize academic information in college, and they should be encouraged and motivated to use reliable and valid sources. The positive feedback from students about the concept of open access should be kept in mind. Students have positive attitudes and clear ideas, and, now, they simply need to be implemented. 


\section{References}

Anderson, T. (2013). Open access scholarly publications as OER. International Review of Research in open and Distance Learning, 14(2), 81-95. Retrieved from http:// www.irrodl.org/index.php/irrodl/article/ view/ 1531

Antelman, K. (2004). Do open-access articles have a greater research impact? College \& Research Libraries, 65(5), 372-382. Retrieved from http:// eprints.rclis.org/archive/ 00002309/

Berlin Declaration on Open Access to Knowledge in the Sciences and Humanities. (2003). Berlin. Retrieved from http:// oa.mpg.de/lang/ en-uk/ berlinprozess/berliner-erklarung/

Bethesda Statement on Open Access Publishing. (2003). Retrieved from http:// dash.harvard.edu/bitstream/handle/1/4725199/suber_bethesda.htm?se quence $=1$

Björk, B., Welling, P., Laakso, M., Majlender, P., Hedlund, T., \&Guonason, G. (2010). Open access to the scientific journal literature: Situation 2009. PLoS ONE, 5(6), e11273. doi:10.1371/journal.pone.0011273. Retrieved from http:// www.plosone.org/article/info:doi/ 10.1371/journal.pone.0011273

Cohen, L., Manion, L., \& Morrison, K. (2000). Research methods in education. London and New York: Routledge Falmer.

Craig, I., Plume, A., McVeigh, M.E., Pringle, J ., \& Amin, M. (2007). Do open access articles have greater citation impact? A critical review of the literature. J ournal of Infometrics, 1, 239-248.

Creswell, J . W. (2003). Research design: Qualitative, quantitative, and mixed methods approach. Thousand Oaks, CA: Sage.

Davis, P. M. (2011). Open access, readership, citations: A randomized controlled trial of scientific journal publishing. The FASEB J ournal, 25, 2129-2134. Retrieved from http:// www.fasebj.org/ content/ 25/ 7/2129.full.pdf+html

Evans, J . A., \& Reimer, J . (2009). Open access and global participation in science. Science, 323 (5917), 1025-1025. Retrieved from http://dx.doi.org/ 10.1126/ science.1154562

Eysenbach, G. (2006). Citation advantage of open access articles. PLoS Biology, 4, e157. Retrieved from http:// www.plosbiology.org/article/info:doi/10.1371/journal.pbio.0040157

Goetz, J . P., \&LeCompte, M. D. (1988). Ethnography and qualitative design in educational research. Madrid: Ediciones Morata. 
Harnad, S., \& Brody, T. (2004). Comparing the impact of open access (OA) vs non-OA articles in the same journals. D-Lib Magazine, 10(6). Retrieved from http:// www.dlib.org/ dlib/june04/harnad/06harnad.html

Institute for Scientific Information (2004). The impact of open access journals: A citation study from Thomson ISI. Retrieved from http:// www.thomsonscientific.jp/ event/oal/impact-oa-journals.pdf

Lawrence, S. (2001). Free online availability substantially increases a paper's impact. Nature, 412(6846), 477.

Levin, J ., Burbules, N., \& Bruce, B. (2005). From student work to exemplary educational resources: The case of the CTER white papers. E-Learning, 2(1), 39- 49. Retrieved from https:// www.ideals.illinois.edu/bitstream/handle/2142/16662/CTER_white_p apers.pdf? sequence=2.

Lynch, C., \& Lippincott, J . (2005). Institutional repository deployment in the United States as of early 2005. D-Lib Magazine, 11(9), 1- 11. Retrieved from http:// webdoc.sub.gwdg.de/ edoc/aw/dlib/dlib/september05/lynch/09lynch.html

McCabe, M. J ., \& Snyder, C. M. (2011). Did online access to journals change the economics literature? Social Science Research Network. Retrieved from http:// www.ssrn.com/ abstract=1746243

Norris, M., Oppenheim, C., Rowland, F. (2008). The citation advantage of open-access articles. J ournal of the American Society for Information Science and Technology, 59, 1963- 1972. Retrieved from http:// hdl.handle.net/2134/4083

Open Society Institute (OSI). (2002). Budapest open access initiative (BOAI). Retrieved from http:// www.budapestopenaccessinitiative.org/ read

Shields, P., Rangarajan, N., \& Stewart, L. (2012). Open access digital repository: Sharing student research with the world. J ournal of Public Affairs Education, 18(1), 157-181. Retrieved from http:// www.naspaa.org/jpaemessenger/Article/VOL18-1/jpae18_01_final.pdf

Swan, A. (2010). The open access citation advantage: Studies and results to date. Technical Report of School of Electronics \& Computer Science, University of Southampton. Retrieved from http:// eprints.ecs.soton.ac.uk/ 18516

Wagner, A. B. (2010). Open access citation advantage: An annotated bibliography. Issues in Science and Technology Librarianship, 60. Retrieved from http:// www.istl.org/ 10-winter/ article2.html 
Willinsky, J . (2006). The access principle: The case for open access to research and scholarship. Cambridge, MA: MIT Press. Retrieved from http://mitpress.mit.edu/sites/default/files/titles/content/9780262512664_Do wnload the full text.pdf

Zhang, Y. (2006). The effect of open access on citation impact: A comparison study based on web citation analysis. Libri, 56(3), 133-199. Retrieved from http:// librijournal.org/pdf/2006-3pp145-156.pdf

\section{Athabasca University $\mathbf{a}$}

(9) (1) 